\title{
How does the Taquari River influence in the cladoceran assemblages in three oxbow lakes?
}

\author{
Panarelli, EA. ${ }^{a,{ }^{*}}$, Güntzel, AM. ${ }^{b}$ and Borges, $C N{ }^{a}$ \\ ${ }^{a}$ Universidade Estadual de Minas Gerais, Av. Prof. Mario Palmério 1001, 38200-000 Frutal, MG, Brazil \\ ${ }^{b}$ Universidade Estadual do Mato Grosso do Sul, Rua General Mendes de Moraes 370, 79400-000 Coxim, MS, Brazil \\ 'e-mail: epanarelli@ig.com.br
}

Received July 16, 2012 - Accepted November 5, 2012 - Distributed November 29, 2013

(With 6 figures)

\begin{abstract}
This study examined the cladoceran assemblages in three oxbow lakes of the Taquari River floodplain, near the transition between the plateau and the plain. We sought to answer the following questions: does the Taquari River function as a geographical barrier or dispersal corridor for Cladocera? Can different degrees of connection induce different structures in the assemblages in each lake? Cladocerans and limnological variables were sampled every other month for one year. Forty-one species were recorded, four of which were common to all the lakes. Our results indicated that the different degrees of connection between the river and the oxbow lakes favoured environmental heterogeneity and diversification in the cladoceran assemblages. The greatest dissimilarity between the two lakes connected with the river indicates that in this case the river functions better as a barrier than a dispersal corridor.
\end{abstract}

Keywords: Cladocera, diversity, dispersal, floodplain, oxbow lakes.

\section{Qual a influência do rio Taquari nas assembleias de Cladocera em três lagoas marginais?}

\section{Resumo}

Assembleias de cladóceros foram avaliadas em três lagoas marginais ao rio Taquari, próximo à transição entre planalto e planície. As seguintes questões foram investigadas: O rio Taquari funciona como barreira ou corredor de dispersão para Cladocera? O grau de conexão induz a diferentes estruturas nas assembleias de cada lagoa? Cladocera e variáveis limnológicas foram amostradas a cada dois dias durante um ano. Foram registradas 41 espécies, apenas 4 comuns em todas as lagoas. Nossos resultados apontam que diferentes graus de conexão entre rio e lagoas favorecem a heterogeneidade ambiental e a diversificação das assembleias de cladóceros. A maior dissimilaridade entre as duas lagoas conectadas com o rio indica que, neste caso, o rio funciona melhor como barreira do que como corredor de dispersão.

Palavras chave: Cladocera, diversidade, dispersão, planície de inundação, lagoas marginais.

\section{Introduction}

River flood pulses are known to drive ecological processes in the adjacent floodplain, providing conditions for the establishment of complex environmental heterogeneity. In South America, several investigators have examined this theme, among them Junk (1980) and Neiff (1997). In the last 40 years, with the creation of the Ramsar Convention on Wetlands, the importance of these systems for aquatic biodiversity conservation has been extensively discussed.

In view of the importance of floodplains for the maintenance of biodiversity, and the considerable importance of microcrustaceans at the base of aquatic trophic relationships, it is surprising that so little is known about this group in one of the largest floodplain systems of the world, the Pantanal. A review by Hollwedel et al. (2003) listed 14 articles with records of microcrustacean species and emphasised the lack of information for this region. After this, few studies have contributed to the records of cladoceran species in the Pantanal, among them, only Guntzel et al. (2010) has registered cladocerans in the Taquari River floodplain, in the same lakes dealt with in this study, but they only analysed the local diversity for each one of the lakes. Studies focusing the patches dynamics for cladocerans, such as the studies conducted by Cottenie and De Meester (2003), Cottenie et al. (2003) and Declerck et al. (2011), are rare in Brazilian landscapes, but they are necessary to understand the diversity of cladocerans in systems of the Pantanal.

In this study, the Cladocera species was surveyed in three oxbow lakes and in the Taquari River, attempting to understand the river influence on the dispersal and composition of cladoceran assemblages. A small extension of floodplain was studied; however, it constitutes a hetero- 
geneous system of patches (three lakes) connected by the river (dispersal corridor), so we analysed the local (alpha diversity) regional diversity (beta diversity) for this research. We also attempted to determine if the river functions as a corridor or as a barrier for dispersal of cladocerans, and how the limnological conditions influenced by the river pulse may promote differentiation upon the structure of the local cladoceran assemblages. Thus, both the dispersal and niche characteristics were considered.

\section{Study Site}

Sampling was carried out in three oxbow lakes (L1, L2 and L3) and three sites in the Taquari River (R1, R2 and R3), adjacent to each lake. This region is located in the Paraguay River watershed near the eastern boundary of the Pantanal plain, where the river begins the formation of a large alluvial fan. At this location, the Taquari River flow is between 1.11 and $1.39 \mathrm{~m} \mathrm{~s}^{-1}$ (Jongman, 2005).

The region has a semi-humid tropical climate, the local flood pattern is unimodal (Hamilton, 1998). A better characterisation of the watershed can be found in Galdino et al. (2005) and the geomorphological characteristics were described by Ab'Saber (2006) and Mercante et al. (2011).

The oxbow lakes studied are close to each other (see Figure 1 and Geographical coordinates as shown in Table 1), L1 is the smallest in both depth and surface area, without a river connection during this study, colonized by several groups of macrophytes; the riparian vegetation is well preserved. L2 is intermediate in size, with inflow from the Taquari River normally only from December to March; most of its surface is covered by Eichhornia azurea. This lake receives crystalline water from a stream, exported it to Taquari River during the dry months. L3 is the deepest and largest in area, with a permanent river connection, degraded riparian vegetation, and human influence on the macrophyte beds.
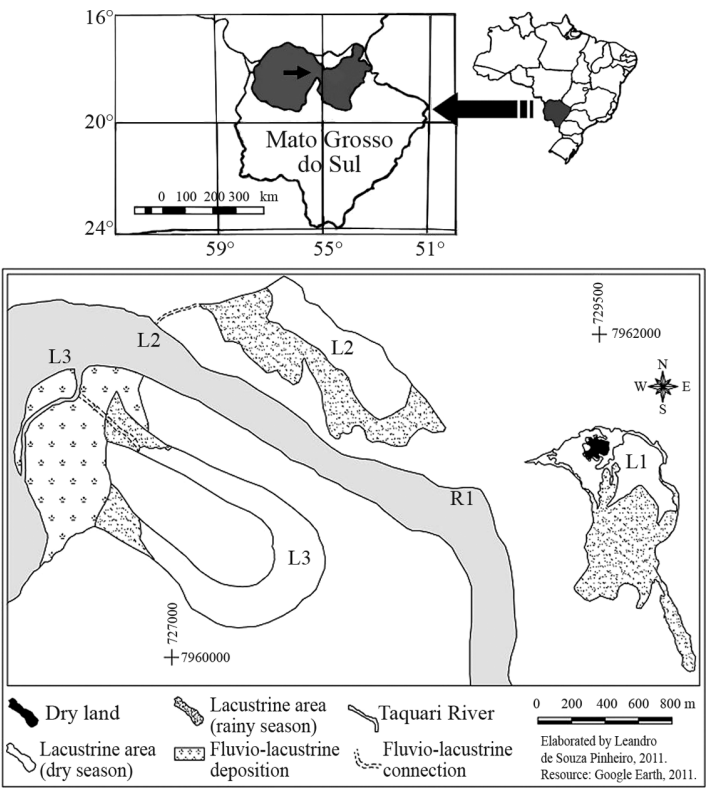

Figure 1 - Location of Mato Grosso do Sul State and the Taquari River basin. The arrow indicates the stretch of floodplain studied (above) and the sampling sites are represented below: lakes (L1, L2 and L3) and river (R1, R2 and R3). Illustration by Leandro de Souza Pinheiro.

\section{Methodology}

Sampling was conducted in the limnetic zone of the lakes and in the river channel near each lake, bimonthly over one year, August 2005 through July 2006. Cladocerans were collected by vertical hauls with plankton net (50 $\mu \mathrm{m}$ mesh). In the river, a bucket was used to collect the surface water. The organisms were fixed with $4 \%$ formaldehyde. The abundance of Cladocera was quantified; Shannon-Wiener diversity $\alpha$ (H') and evenness (H'/max H') were estimated according to Krebs (1999) and beta diversity, Whittaker's measure, according to Magurran (2003) and Wilson and Shmida, (1984). The limnological variables (see Table 2 ) were used to characterise the environmental conditions of the lakes and to evaluate the influence of the river on each lake. Six cases

Table 1 - Geographical coordinates, altitude and depth of the oxbow lakes and the Taquari River.

\begin{tabular}{|c|c|c|c|c|c|c|}
\hline & L1 & $\mathbf{L} 2$ & L3 & R1 & $\mathbf{R 2}$ & $\mathbf{R 3}$ \\
\hline Geographical coordinates & $\begin{array}{l}18^{\circ} 25^{\prime} 38^{\prime \prime} \mathrm{S} \\
54^{\circ} 49^{\prime} 44^{\prime \prime} \mathrm{W}\end{array}$ & $\begin{array}{l}18^{\circ} 25^{\prime} 19^{\prime \prime} \mathrm{S} \\
54^{\circ} 50^{\prime} 41^{\prime \prime} \mathrm{W}\end{array}$ & $\begin{array}{l}18^{\circ} 25^{\prime} 58^{\prime \prime} \mathrm{S} \\
54^{\circ} 51^{\prime} 8^{\prime \prime} \mathrm{W}\end{array}$ & $\begin{array}{l}18^{\circ} 25^{\prime} 45^{\prime \prime} \mathrm{S} \\
54^{\circ} 500^{\prime} 01^{\prime \prime} \mathrm{W}\end{array}$ & $\begin{array}{l}18^{\circ} 25^{\prime} 17^{\prime \prime} \mathrm{S} \\
54^{\circ} 51^{\prime} 15^{\prime \prime} \mathrm{W}\end{array}$ & $\begin{array}{l}18^{\circ} 25^{\prime} 35^{\prime \prime} \mathrm{S} \\
54^{\circ} 51^{\prime} 40^{\prime \prime} \mathrm{W}\end{array}$ \\
\hline Altitude (m) & 196 & 194 & 189 & 190 & 190 & 189 \\
\hline \multicolumn{7}{|l|}{ Surface area } \\
\hline Rainy period & $164,089 \mathrm{~m}^{2}$ & $252,582 \mathrm{~m}^{2}$ & $456,575 \mathrm{~m}^{2}$ & - & - & - \\
\hline Dry period & $526,495 \mathrm{~m}^{2}$ & $601,921 \mathrm{~m}^{2}$ & $574,974 \mathrm{~m}^{2}$ & - & - & - \\
\hline $\begin{array}{l}\text { Maximum depth (m) (in } \\
\text { February 2006) }\end{array}$ & 1.80 & 3.75 & 5.0 & - & - & - \\
\hline
\end{tabular}


Table 2 - Limnological variables and methodology.

\begin{tabular}{ll}
\hline Variable & Methodology \\
\hline Water temperature $\left({ }^{\circ} \mathrm{C}\right)$ & Conductivimeter (Tecnopon, MCA 150 P) \\
Dissolved oxygen $\left(\mathrm{mg} \mathrm{L}^{-1}\right)$ & Oximeter (YSI 55); \\
$\mathrm{pH}$ & Potentiometer (Tecnopon, MPA 210P) \\
Electrical conductivity $\left(\mu \mathrm{S}_{\mathrm{cm}}{ }^{-3}, 25^{\circ} \mathrm{C}\right)$ & Conductivimeter (Tecnopon, MCA 150 P) \\
Water transparency $(\mathrm{m})$ & Secchi disk (30 cm diameter) \\
Suspended matter $\left(\mathrm{mg} \mathrm{L}^{-1}\right)($ Organic and inorganic particulate) & Gravimetric (according to Cole, 1979) \\
\hline
\end{tabular}

were considered for each variable for each location. The statistical package "R development core team" (2011) was used to evaluate the dissimilarities of the limnological variables between locations, including river sampling stations. Cluster analysis was performed using Euclidean distance by Ward's methodology. Dissimilarities between lake assemblages and their correlations (r) to limnological variables were estimated according to ordination analysis, "Non-metric Multidimensional Scaling" (NMDS) only for the sampling stations of the oxbow lakes, due to the low richness and density in the river.

\section{Results}

\subsection{Limnological parameters}

Wide amplitude of dissolved oxygen and temperature with low dissolved-oxygen concentrations are limnological characteristics that make these lacustrine systems similar to each other compared to the lotic system. Nevertheless, the existence of different degrees of con- nection between the river and the lakes promoted heterogeneous pattern among the lentic systems (see Table 3 ).

$\mathrm{L}_{1}$ and $\mathrm{L}_{2}$ were more similar to each other than to $\mathrm{L} 3$. During the study period, L1 had no connectivity and the lowest dissolved-oxygen concentration and suspended matter, with a high organic-matter content.

In $\mathrm{L} 2$, river input occurred on $33 \%$ of the days analysed when the river at the city of Coxim was above $3.66 \mathrm{~m}$ (Figure 2). The river input caused a sharp reduction of water transparency and increase in electrical conductivity, with extreme values recorded in February 2006, respectively: $0.30 \mathrm{~m}$ and $18.87 \mu \mathrm{S} \mathrm{cm}^{-2}$. In other months, the transparency was total and the conductivity ranged from 5.04 to $8.34 \mu \mathrm{S} \mathrm{cm}^{-2}$.

L3 remained connected during the entire studied period. In this lake, the lowest water transparency and the highest electrical conductivity and $\mathrm{pH}$ was observed, due to the greater influence of the river (Figure 3).

$\mathrm{L}_{2}$ waters were exported to the river during most of the year, thus $\mathrm{R}_{2}$ was most similar to the lakes. This site showed lower values of temperature, dissolved oxygen,

Table 3 - Limnological variables in the oxbow lakes and the Taquari River, as mean (minimum-maximum), from August 2005 through June 2006.

\begin{tabular}{lcccccc}
\hline & $\mathbf{L 1}$ & $\mathbf{L 2}$ & $\mathbf{L 3}$ & $\mathbf{R 1}$ & $\mathbf{R 2}$ & $\mathbf{R 3}$ \\
\hline Water temperature & 26.67 & 26.27 & 28.43 & 26.11 & 25.64 & 26.77 \\
& $(21.60-31.20)$ & $(21.90-31.90)$ & $(22.40-34.50)$ & $(21.90-28.90)$ & $(21.70-29.20)$ & $(22.10-29.70)$ \\
Dissolved oxygen & 3.02 & 5.70 & 5.69 & 7.75 & 5.78 & 7.71 \\
& $(1.57-6.05)$ & $(3.66-7.61)$ & $(4.16-8.28)$ & $(6.70-9.80)$ & $(3.98-7.02)$ & $(6.32-9.09)$ \\
Electrical conductivity & 7.26 & 6.99 & 32.85 & 24.62 & 12.19 & 23.05 \\
& $(5.61-10.80)$ & $(3.38-18.87)$ & $(24.80-39.40)$ & $(22.30-26.90)$ & $(4.60-25.20)$ & $(20.00-26.50)$ \\
pH & 5.09 & 5.05 & 5.97 & 6.64 & 5.33 & 6.23 \\
& $(3.06-5.79)$ & $(3.36-5.78)$ & $(5.01-7.09)$ & $(5.35-7.45)$ & $(2.89-6.65)$ & $(5.17-7.90)$ \\
Water transparency & 1.24 & 1.32 & 0.40 & -- & -- & -- \\
& $(1.00-1.18)$ & $(0.30-2.03)$ & $(0.15-0.86)$ & & & 10.16 \\
Suspended matter & 1.53 & 5.92 & 6.54 & 9.99 & 6.42 & $(5.00-17.40)$ \\
& $(0.00-4.50)$ & $(0.50-21.00)$ & $(1.25-12.50)$ & $(6.00-16.10)$ & $(0.00-21.50)$ & 1.21 \\
Organic matter & 1.05 & 0.72 & 1.46 & 1.38 & 1.19 & $(0.60-2.00)$ \\
& $(0.00-4.00)$ & $(0.00-2.00)$ & $(0.50-4.60)$ & $(0.00-3.50)$ & $(0.00-2.50)$ & 8.95 \\
Inorganic matter & 0.48 & 5.20 & 5.08 & 8.61 & 5.23 & $(4.00-16.20)$ \\
\hline
\end{tabular}




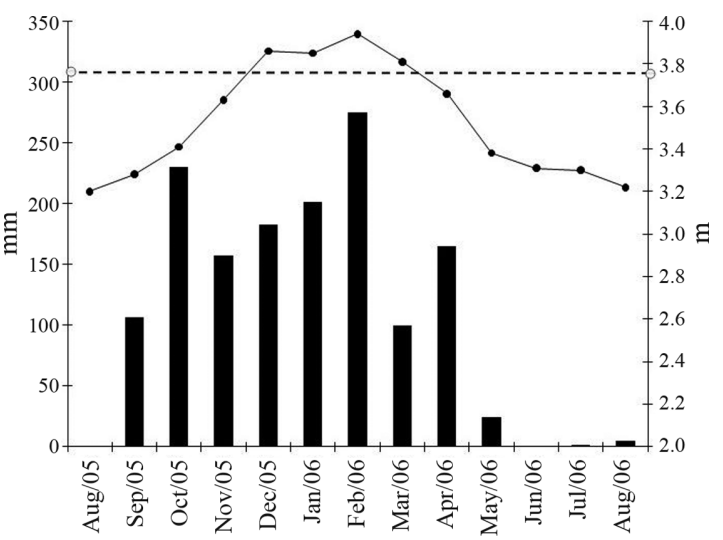

Figure 2 - Precipitation (mm) in bar, water level variation (m) in solid line. The limit of the Taquari River inflow into L2 is shown by the dashed line; inflow occurred above the river level of $3.66 \mathrm{~m}$.

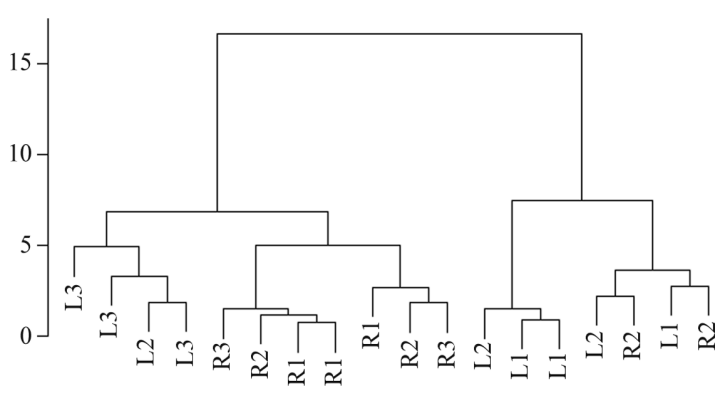

Figure 3 - Dissimilarity between sampling locations in relation to the limnological variables (Euclidean distance).

electrical conductivity, $\mathrm{pH}$ and suspended matter, the opposite of what was found in R1 and R3 (as shown in Table 3).

\subsection{Cladoceran assemblages}

The species composition in each environment studied is listed in Table 4. In all, 41 species were recorded: 7 only in L1, 9 only in L2, and 8 in L3 (Figure 4). In L2, where 22 species were recorded, 19 were species of the family Chydoridae; species of Macrothricidae and Ilyocryptidae were also registered. In L1, 21 species were found, and in L3 17 species, in 6 and 7 families: Chydoridae, Sididae, Daphniidae, Bosminidae, Ilyocriptidae, Macrothicidae and Moinidae. This last family was restricted to L3 (see Table 4).

Only 4 species were common to the three lakes: Ilyocryptus spinifer, Macrothrix squamosa, Alonella dadayi and Chydorus pubescens; 8 species were common to L1 and L2; 3 species were common to L1 and L3; and only 2 species were found in both L2 and L3 (Figure 4). The list of species includes 4 new records for the region. The record of Bosminopsis brandorffi, based on a small number of individuals, should be more thoroughly exam-

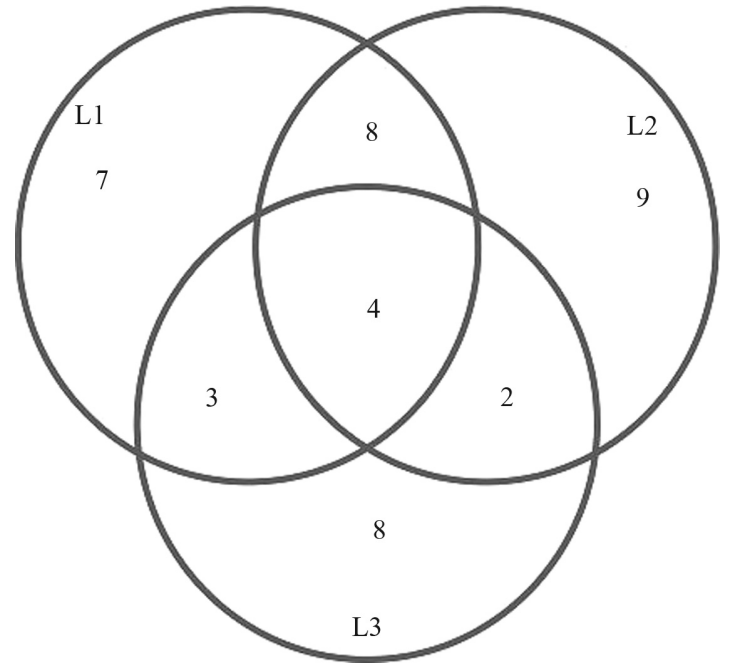

Figure 4 - Number of species of Cladocera in each lake; the intersections indicate the presence of the species in more than one lake.

ined, since this species is considered endemic to the Amazon watershed.

Differences in cladoceran densities were also observed among lakes: higher mean densities were observed in L3 $\left(36,988\right.$ ind. $\left.\mathrm{m}^{-3}\right)$ compared to L1 $(3,344$ ind. $\mathrm{m}^{-3}$ ) and L2 (439 ind. $\left.\mathrm{m}^{-3}\right)$. In L3 the higher densities were concentrated mainly in the families Moinidae $\left(17,608\right.$ ind. $\left.\mathrm{m}^{-3}\right)$, Sididae $\left(10,124\right.$ ind. $\left.\mathrm{m}^{-3}\right)$ and Bosminidae $\left(8,916\right.$ ind. $\left.\mathrm{m}^{-3}\right)$; in L1 higher densities were recorded for families Chydoridae $\left(1,468\right.$ ind. $\left.\mathrm{m}^{-3}\right)$ and Bosminidae (1,072 ind. $\left.\mathrm{m}^{-3}\right)$; and in L2 the density was almost entirely due to Chydoridae (339 ind. $\mathrm{m}^{-3}$ ).

Cladoceran density was low in the river (see Figure 5), where Macrothricidae was the most abundant family (mean 25 ind. $\mathrm{m}^{-3}$ ). Richness was also low; only 13 of the total of 41 species were recorded in the river, and, in addition, the species found in the river were also recorded in the nearest lake (as shown in Table 4). Only Leydigia striata was recorded exclusively in the river.

Three species of limnetic cladocerans were constant and abundant in L3, with the following mean densities: Moina minuta $\left(17,608\right.$ ind. $\left.\mathrm{m}^{-3}\right)$, Diaphanosoma fluviatile $\left(10,015\right.$ ind. $\left.\mathrm{m}^{-3}\right)$ and Bosminopsis deitersi $\left(8,916\right.$ ind. $\left.\mathrm{m}^{-3}\right)$. Wider variations of species were observed in the other lakes, with limnetic species rarely present in L1 and totally absent in L2. Alpha diversity was highest in L2 not only because of higher richness, but mainly because of elevated evenness values. The widest variation of richness and evenness were observed in L1, thus causing a greater variation in diversity during the year. Beta diversity indicated more similar assemblages between L1 and L2, and greater dissimilarity between L2 and L3 (see Table 5). Nevertheless, during river input in L2, higher richness values were found in L2 and L3, while the lowest value occurred in L1. 
Table 4 - List of species of Cladocera recorded, presence (X) of each species, and richness in the lakes and river from August 2005 through June 2006, (*) Indicates first record from the Pantanal and $(* *)$ indicates recent change of the genus.

\begin{tabular}{|c|c|c|c|c|c|c|}
\hline & $\mathbf{L 1}$ & $\mathbf{L 2}$ & $\mathbf{L 3}$ & R1 & $\mathbf{R 2}$ & R3 \\
\hline \multicolumn{7}{|l|}{ Ctenopoda } \\
\hline \multicolumn{7}{|l|}{ Sididae Baird, 1850} \\
\hline Diaphanosoma birgei Korinek, 1981 & & & $\mathrm{X}$ & & & \\
\hline Diaphanosoma fluviatile Hansen, 1899 & $\mathrm{X}$ & & $\mathrm{X}$ & & & \\
\hline Diaphanosoma brevireme Sars, 1901 & & & $\mathrm{X}$ & & & \\
\hline Diaphanosoma spinulosum Herbs, 1975 & & & $\mathrm{X}$ & & & $\mathrm{X}$ \\
\hline Sarsilatona serricauda (Sars, 1901) & $\mathrm{X}$ & & & & & \\
\hline \multicolumn{7}{|l|}{ Anomopoda } \\
\hline \multicolumn{7}{|l|}{ Moinidae Goulden, 1968} \\
\hline Moina minuta Hansen, 1899 & & & $\mathrm{X}$ & & & $\mathrm{X}$ \\
\hline \multicolumn{7}{|l|}{ Daphniidae Straus, 1820} \\
\hline Ceriodaphnia cornuta (Sars, 1885) & & & $\mathrm{X}$ & & & \\
\hline Ceriodaphnia rigaudi Sars, 1886 & & & $\mathrm{X}$ & & & $\mathrm{X}$ \\
\hline Ceriodaphnia silvestrii Daday, 1902 & $\mathrm{X}$ & & $\mathrm{X}$ & & & \\
\hline \multicolumn{7}{|l|}{ Bosminidae Sars, 1865} \\
\hline *Bosminopsis cf. brandorffi Rey and Vásquez, 1989 & $\mathrm{X}$ & & & & & \\
\hline Bosminopsis deitersi Richard, 1895 & $\mathrm{X}$ & & $\mathrm{X}$ & & & $\mathrm{X}$ \\
\hline \multicolumn{7}{|l|}{ Ilyocryptidae Smirnov, 1992} \\
\hline Ilyocryptus spinifer Herrick, 1882 & $\mathrm{X}$ & $\mathrm{X}$ & $\mathrm{X}$ & & & \\
\hline \multicolumn{7}{|l|}{ Macrothricidae Norman and Brady, 1867} \\
\hline Macrotrix squamosa Sars, 1901 & $\mathrm{X}$ & $\mathrm{X}$ & $\mathrm{X}$ & $\mathrm{X}$ & $\mathrm{X}$ & \\
\hline Macrothrix superaculeata (Smirnov, 1902) & $\mathrm{X}$ & $\mathrm{X}$ & & & & $\mathrm{X}$ \\
\hline Macrotrix paulensis (Sars, 1901) & $\mathrm{X}$ & & & & & \\
\hline \multicolumn{7}{|l|}{ Chydoridae Stebbing, 1902} \\
\hline Acroperus tupinamba Sinev and Elmoor-Loureiro, 2010 & $\mathrm{X}$ & $\mathrm{X}$ & & & & \\
\hline Alonella clatrhatula Sars, 1896 & $\mathrm{X}$ & & & & & \\
\hline Alonella dadayi Birge, 1910 & $\mathrm{X}$ & $\mathrm{X}$ & $\mathrm{X}$ & & $\mathrm{X}$ & \\
\hline Chydorus eurinotus Sars, 1901 & & $\mathrm{X}$ & & & & \\
\hline Chydorus nitidulus (Sars, 1901) & & $\mathrm{X}$ & & & & \\
\hline Chydorus pubescens Sars, 1901 & $\mathrm{X}$ & $\mathrm{X}$ & $\mathrm{X}$ & $\mathrm{X}$ & $\mathrm{X}$ & \\
\hline Disparalona leptohyncha Smirnov, 1996 & & $\mathrm{X}$ & & & & \\
\hline Dunhevedia odontoplax Sars, 1901 & & $\mathrm{X}$ & $X$ & & & \\
\hline Ephemeroporus barroisi (Richard, 1894) & & $\mathrm{X}$ & & & & \\
\hline Ephemeroporus hibridus (Daday, 1905) & $\mathrm{X}$ & $\mathrm{X}$ & & & & \\
\hline Ephemeroporus tridentatus (Bergamin, 1931). & $\mathrm{X}$ & & & & & \\
\hline *Euryalona brasiliensis Brehm and Thomsen, 1936 & & & $\mathrm{X}$ & & & \\
\hline *Picripleuroxus cf. similis (Vávra, 1900) & & & $\mathrm{X}$ & $\mathrm{X}$ & $\mathrm{X}$ & \\
\hline *Pleuroxus cf. aduncus (Jurine, 1820) & $\mathrm{X}$ & & & & $\mathrm{X}$ & \\
\hline \multicolumn{7}{|l|}{ Aloninae Frey, 1967} \\
\hline Alona broaensis Matsumura-Tundisi and Smirnov, 1984 & $\mathrm{X}$ & & & & & \\
\hline Alona guttata Sars, 1862 & & $\mathrm{X}$ & & & & \\
\hline Alona iheringula Sars, 1901 & & $\mathrm{X}$ & & & & \\
\hline
\end{tabular}


Table 4 (cont.)

\begin{tabular}{|c|c|c|c|c|c|c|}
\hline & $\mathbf{L 1}$ & $\mathbf{L 2}$ & $\mathbf{L 3}$ & $\mathbf{R 1}$ & $\mathbf{R 2}$ & $\mathbf{R 3}$ \\
\hline Alona intermedia Sars, 1862 & $\mathrm{X}$ & $\mathrm{X}$ & & & $\mathrm{X}$ & $\mathrm{X}$ \\
\hline Alona ossiani Sinev, 1998 & $\mathrm{X}$ & $\mathrm{X}$ & & & & \\
\hline Alona sp. Baird, 1840 & & $\mathrm{X}$ & & & & \\
\hline Alona verrucosa Sars, 1901 & $\mathrm{X}$ & $\mathrm{X}$ & & & & \\
\hline Camptocercus australis Sars, 1896 & & $\mathrm{X}$ & & & & \\
\hline **Coronatella rectangula (Sars, 1861$)$ & & $\mathrm{X}$ & $\mathrm{X}$ & $\mathrm{X}$ & $\mathrm{X}$ & \\
\hline Leydigia striata Berabén, 1939 & & & & $\mathrm{X}$ & & \\
\hline Leydigiopsis cf. curvicornis Sars, 1901 & $\mathrm{X}$ & & & & & \\
\hline *Nicsmirnovius incredibilis (Smirnov, 1984). & & $\mathrm{X}$ & & & & \\
\hline Richness of species: 41 & 21 & 21 & 17 & 4 & 7 & 6 \\
\hline
\end{tabular}
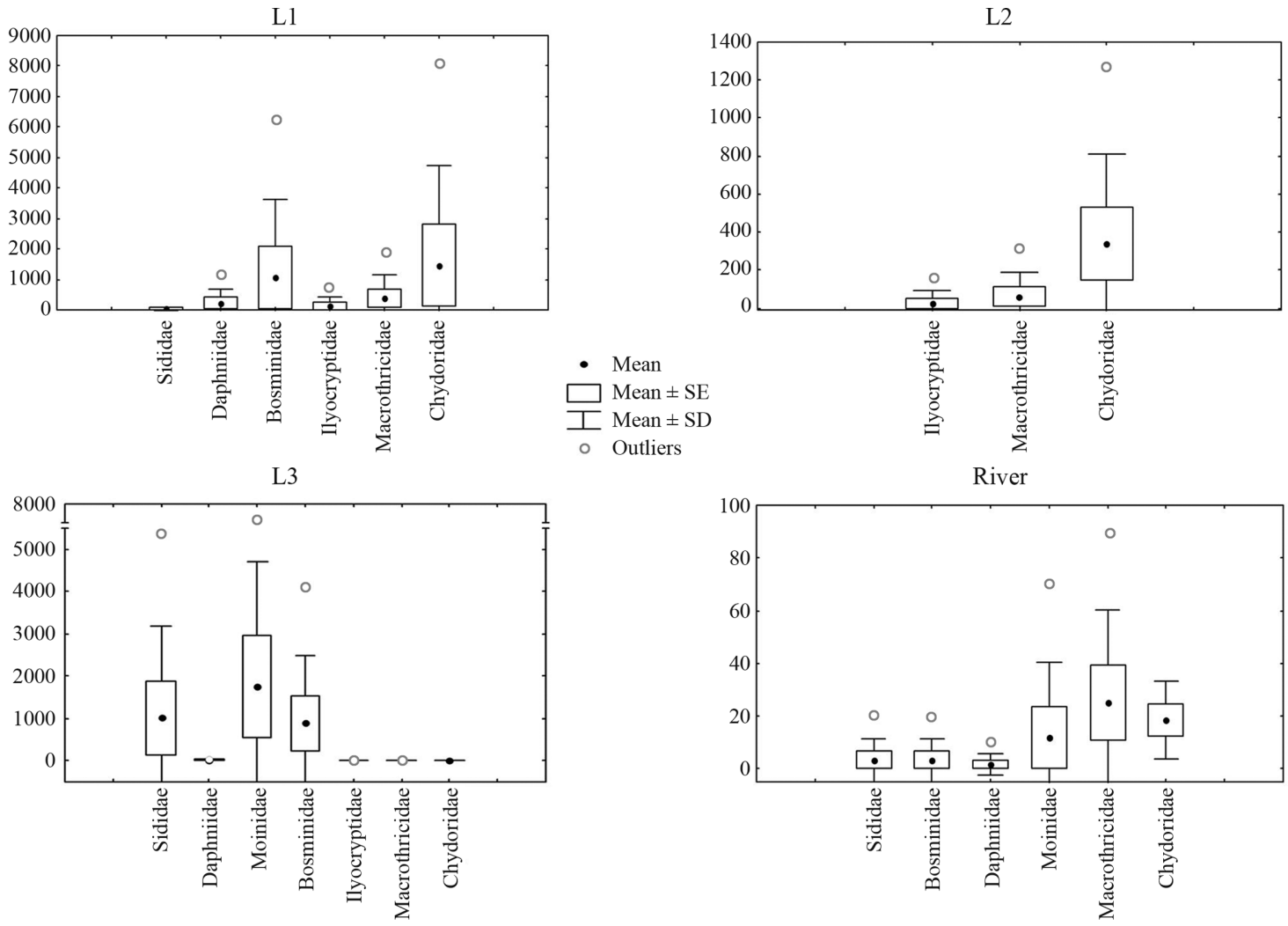

Figure 5 - Mean, standard error and deviation for families of Cladocera (ind. $\mathrm{m}^{-3}$ ) in three oxbows lakes (L1, L2 and L3) and in the Taquari River (sum of river sampling stations).

Greater dissimilarity between L2 and L3 was also confirmed by the ordination analysis (NMDS), which separated L3 from the other lakes, mainly L2, based on densities of cladocerans and correlations to the limnological variables (as shown in Figure 6). Electrical conductivity $(\mathrm{r}=0.59 ; \mathrm{p}=0.013)$ and water transparency $(\mathrm{r}=0.361 ; \mathrm{p}=0.100)$ were the variables that best explained the distribution of cladocerans in the lakes.

\section{Discussion}

In the local of this investigation, the flow of the Taquari River slows, with a resulting increase in sedimentation, producing oxbow lakes, swamps and other types of wetland subsystems that produce a "macrosystem". These subsystems are subject to floods (pota- 
Table 5 - Richness, evenness, alpha diversity (Shannon-Wiener) and beta diversity, estimated bimonthly in three oxbow lakes.

\begin{tabular}{lccccccc}
\hline & & Aug/2005 & Oct/2005 & Dec/2005 & Feb/2006 & Apr/2006 & Jun/2006 \\
\hline \multirow{2}{*}{ Richness } & L1 & 8 & 5 & 1 & 2 & 4 & 11 \\
& L2 & 8 & 8 & 6 & 12 & 5 & 5 \\
\hline \multirow{2}{*}{ Evenness } & L3 & 3 & 6 & 8 & 11 & 5 & 4 \\
& L1 & 0.25 & 0.89 & 0.00 & 1.00 & 1.66 & 3.20 \\
& L2 & 0.93 & 0.94 & 0.93 & 0.88 & 0.97 & 0.97 \\
Diversity & L3 & 0.97 & 0.43 & 0.80 & 0.90 & 0.56 & 0.87 \\
& L1 & 0.74 & 2.06 & 0.00 & 1.00 & 0.83 & 0.93 \\
& L2 & 2.80 & 2.83 & 2.41 & 3.16 & 2.25 & 2.25 \\
& L3 & 1.54 & 0.89 & 2.39 & 3.13 & 1.30 & 1.74 \\
\hline
\end{tabular}

Beta diversity: $\mathrm{L} 1$ and $\mathrm{L} 2=0.524 \mathrm{~L} 2$ and $\mathrm{L} 3=0.684 \mathrm{~L} 1$ and $\mathrm{L} 3=0.632$.

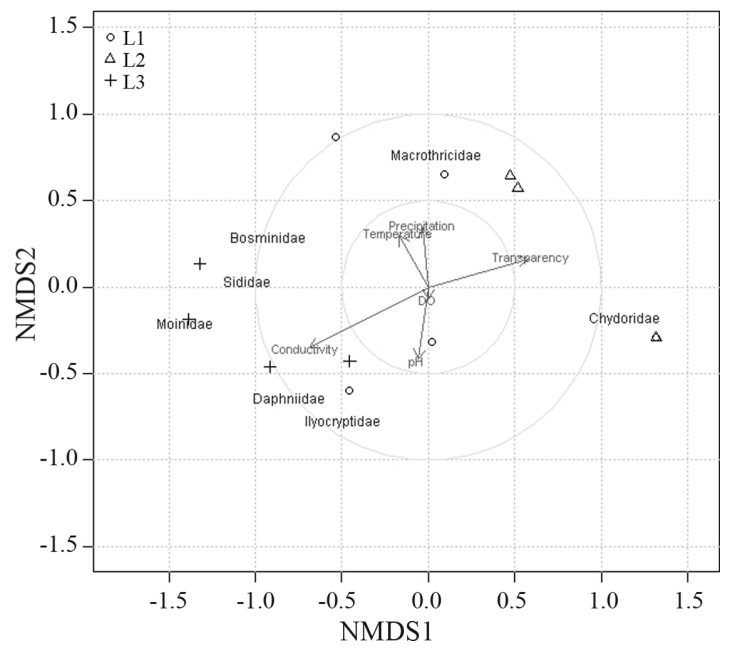

Figure 6 - Dissimilarities among the composition of families of Cladocera in three oxbow lakes (L1, L2 and L3). correlated to limnological variables according to Non-metric Multidimensional Scaling (NMDS).

mophase) or remain isolated in the dry season (limnophase), according to Neiff (1997).

Ranging from 4 metres in years with little rain, to 6 metres when precipitation is high (Jongman, 2005), the Taquari River can flood the lateral systems to different degrees in different years: some remain connected, others receive river input in annual flooding, and others only in extreme flooding. Habitat heterogeneity, as much in the temporal as in the spatial dimension, is the key to maintenance of high biological diversity in the floodplain.

In the limnophase, the limnological features in oxbow lakes are influenced predominantly by the internal dynamics of changes between the sediment and the water column, and the functioning of the local community. Each system then becomes differentiated during the dry season. In the flood period, similarity among the systems increases and the limnological conditions and aquatic communities become more homogeneous, as discussed by Thomaz et al. (2007).

The greater dissimilarity of L3 from the other lakes was associated with higher electrical conductivity and low water transparency, as a result of the natural dynamics of the Taquari River, highest cladoceran abundance also was registered in this lake. This influence was strongly enhanced by the ranching and farming activities in the watershed, added to the influence of partial macrophyte removal and the use of the land along the banks, with the riparian vegetation degraded, such characteristics also were observed by Guntzel et al. (2010). The removal of the vegetation from the channel connecting the river to the lake reduced the filtration effect of the plants and increased the lotic influence on the lake.

L1 remained in limnophase during the entire study and had the lowest mean dissolved-oxygen concentration and suspended matter, with higher organic-matter content, indicating the possibility of higher decomposition rates of organic matter derived from the riparian zone or dead macrophytes. The decomposition probably increased the oxygen consumption mainly in the rainy season, with input of organic matter and without renewal from the river water. In these conditions, cladoceran richness decreased, increasing again in the dry season, with higher transparency and water oxygenation, when both planktonic and phytophilous species were present. However, dissolved oxygen was not a variable evidenced by statistical analyses used in this study, but Guntzel et al. (2010) noted positive correlation between richness and dissolved oxygen concentration in L1.

An intermediate situation was observed in L2; when the lake was not connected to the river, transparency reached the bottom and electrical conductivity was lower; the lake became more similar to L3 during the period of Taquari River input. However, when the entire period was considered, L2 and L3 showed greater dissimilarity between the cladoceran assemblages: L3 was 
colonised predominantly by limnetic cladocerans due to both the larger surface area and depth, and L2 was colonised almost exclusively by phytophiles. The extensive macrophyte development and constant washout from the river waters probably prevented the establishment of limnetic species; on the other hand, several species of Chydoridae coexisted in this environment.

The heterogeneity of limnological characteristics is a result of the length and frequency of connection, morphometic features, the influence of the local watershed, or the conditions of riparian vegetation and macrophyte stands. These factors provide distinct opportunities for colonisation of cladocerans in each lake. Apparently, the mere existence of a river connection does not guarantee similarity among different assemblages, considering that greater dissimilarity was observed between the two lakes connected with the Taquari River.

Neiff et al. (2001) considered the river as an important species-dispersal corridor. Thus the assemblages of several oxbow lakes in groups can be understood as a metacommunity. Cottenie et al. (2003) found that both local environmental conditions and zooplankton dispersal between habitats were important to structure the communities of 34 lakes permanently connected by overflows and rivulets in a nature reserve in Belgium. In this case, there was low limitation to dispersal between the lakes. Considering the metacommunity vision, studies about the organism dispersal in distinct patches in the landscape must be done for better understanding of the patterns of cladoceran diversity and abundance, as synthesised by Chase (2005).

Declerck et al. (2011), in 59 Andean shallow lakes, concluded that environmental conditions appeared to be the main factor structuring the community. Similarly, Cottenie and De Meester (2003) indicated the secondary importance of dispersal to structure cladoceran assemblages, verifying the correlation between the water transparency and species richness; however, they found no correlation between richness and macrophyte cover area.

The relationship of a larger river-lake connection to high cladoceran richness was observed by Panarelli et al. (2010) in lakes adjacent to the Paranapanema River (São Paulo), in contrast to our observations for Taquari oxbow lakes. Nevertheless, these authors observed the highest richness and diversity associated with low organism density and extensive macrophyte colonisation, similar to the situation observed for Taquari oxbow lakes. In both cases, higher richness and diversity can be associated with large macrophyte stands and oligotrophic conditions of the system, independently of the size of the river-lake connection.

In contrast to the view of the river as a dispersal corridor, our results lead us to believe that the Taquari River functions as a geographical barrier between L2 and L3, because although both are close and connected to the river, they had very different assemblages. The river may hinder the dispersal of cladocerans, which have limited swimming ability to overcome the river flow. On the other hand, the cladoceran dispersal can be efficient when resting eggs are formed. The absence of planktonic organisms in L2 may be associated with the washout by the river waters and the predominance of planktonic species in L3 may be associated with the larger limnetic zone of this lake.

Our results indicate that the role of the river as a dispersal corridor or geographical barrier to cladocerans should be better evaluated, considering not only the distance between lakes; special attention must be directed to the velocity of the river flow. Rivers with high velocity of flow can be more efficient as a barrier than as a corridor of dispersal to cladocerans. There is need to consider both the active phase and resting eggs for a more complete study about metacommunity dynamics, due to the possibility of the resting eggs overcoming geographic barriers with the help of dispersal vectors (Panov et al., 2004).

The question about the role of the river in cladoceran dispersal was not entirely solved in this investigation. However, it has confirmed that river input changes the limnological characteristics differentially in each lake, favouring the niche diversification and organisation of different Cladocera assemblages. The present study confirms that system heterogeneity in the floodplain favors the biodiversity, mainly in systems with lower antropic influence. Our results agree with Frutos et al. (2006) in research done in a wide extension of the Paraguay watershed floodplain. They concluded that the degree of connectivity with the floodplain and local features were the principal factors on organisation of the zooplankton assemblages.

\section{Acknowledgments}

Thanks to FUNDECT (Proc. No. 41/100.066/2004) for research support.

\section{References}

AB'SABER, AN., 2006. Brasil: paisagens de exceção: o litoral e o Pantanal Mato-grossense: patrimônios básicos. Cotia: Ateliê Editorial.

CHASE, JM., 2005. Towards a really unified theory for metacommunities. Functional Ecology, vol. 19, p. 182186.

COTTENIE, K. and DE MEESTER, L., 2003. Connectivity and cladoceran species richness in a metacommunity of shallow lakes. Freshwater Biology, vol. 48, p. 823-832.

COTTENIE, K., MICHELS, E., NUYTTEN, N. and DE MEESTER, L., 2003. Zooplankton metacommunity structure: regional vs. local processes in highly interconnected ponds. Ecology, vol. 84, p. 991-1000.

DECLERCK, SAJ., CORONEL, JS., LEGENDRE, P. and BRENDONCK, L., 2011. Scale dependency of processes structuring metacommunities of cladocerans in temporary pools of High-Andes wetlands. Ecography, vol. 34, p. 296-305.

FRUTOS, SM., POI DE NEIFF, A. and NEIFF, JJ., 2006. Zooplankton of the Paraguay River, p. A comparison between sections and hydrological phases. Zoological Journal of the Linnean Society, vol. 42, p. 277-288. 
GALDINO, S., VIEIRA, LM. and PELLEGRIN, LM., 2005. Impactos ambientais e sócio-econômicos na Bacia do Rio Taquari - Pantanal. Corumbá: Embrapa Pantanal.

GÜNTZEL, AM., PANARELLI, EA., da SILVA, WM. and ROCHE, KF., 2010. Influence of connectivity on Cladocera diversity in oxbow lakes in the Taquari River floodplain (MS, Brazil). Acta Limnologica Brasiliensia, vol. 22 , p. 93-101

HAMILTON, SK., de SOUZA, OC. and COUTINHO, ME. 1998. Dynamics of floodplain inundation in the alluvial fan of Taquari River (Pantanal, Brazil). Verhandlungen der Internationalen Vereinigung für Limnologie, vol. 26, p. $917-922$.

HOLLWEDEL, W., KOTOV, AA. and BRANDORFF, GO., 2003. Cladocera (Crustácea: Branchiopoda) from the Pantanal (Brazil). Arthropoda Selecta vol. 12, p. 67-93.

JONGMAN, RHG., 2005. Pantanal Taquari: tools for decision making in integrated water management. Wageningen: Alterra. Available from: http://www.cpap.embrapa.br/taquari/Taquari_final.pdf.

JUNK, WJ., 1980. Áreas inundáveis: um desafio para Limnologia. Acta Amazonica, vol. 10, p. 775-795.

KREBS, CJ., Ecological Methodology. 1999. New York: Benjamin/Cummings.

MAGURRAN, AE., 1988. Ecological Diversity and Its Measurement. Princeton: Princeton University Press.
MERCANTE, MA., RODRIGUES, SC and ROSS, JLS., 2011. Geomorphology and hábitat diversity in the Pantanal. Brazilian Journal Biology, vol. 71, p. 233-240.

NEIFF, JJ., 1997. El regimen de pulsos en rios y grandes humedales de Sudamérica. In: MALVÁREZ, AI. and KANDUS, P. (eds.) Tópicos sobre Grandes Humedales Sudamericanos. Montevideo: ORCYTMAB (UNESCO), p. 97-145.

NEIFF, JJ., POI DE NEIFF, ASG. and CASCO, S., 2001. The effect of prolonged floods on Eichhornia crassipes growth in Paraná River floodplain lakes. Acta Limnologica Brasiliensia, vol. 3, p. 51-60.

PANARELLI, EA., CASANOVA, SMC. and HENRY, R., 2010. Secondary production and biomass of Cladocera in marginal lakes after the recovery of their hydrologic connectivity in a river-reservoir transition zone. Lakes and Reservoirs, vol. 15, p. 319-334.

PANOV, VE., KRILOV, PI. and RICCARD, N., 2004. Role of diapause in dispersal and invasion success by aquatic invertebrates. Journal of Limnology, vol. 63, 56-69.

R DEVELOPMENT CORE TEAM, 2011. $R$ : A language and environment for statistical computing. Vienna: R Foundation for Statistical Computing. Available from: http://www.R-project.org.

THOMAZ, SM., BINI, LM. and BOZELLI, RL., 2007. Floods increase similarity among aquatic habitats in riverfloodplain systems. Hydrobiologia, vol. 579, p. 1-13.

WILSON, MV. and SHMIDA, A., 1984. Measuring beta Diversity with presence-absence data. Journal of Ecology, vol. 72, p. 1055-1062. 